\title{
Manuel Zapata Olivella (1920-2004): Pensador político, radical y hereje de a diáspora Africana en las Américas by George Palacios
}

\author{
Dawn F. Stinchcomb • Purdue University
}

Palacios, George. Medellín, Colombia: Editorial Pontificia Bolivariana, 2020; 221 pps. Spanish.

I n 2004, the world lost "la voz más importante de la literatura afro colombiana" It is indisputable that Manuel Zapata Olivella was an intellectual of the highest level; he was a trained medical doctor, an anthropologist and an accomplished writer. He was an award-winning novelist, a poet, a dramaturg, and an essayist. While not the oldest, nor the most famous of the Latin American writers of African descent, he was certainly one of the most popular and most admired, if the number of books and articles published about him and his writings are any indication. This is despite the fact that his actual works have never had the large appeal of Cuba's Nicolás Guillén beyond the audience of scholars of Latin American literature, George Palacios' study of Zapata Olivella's political writing is one of several monographsat least a dozen - that examines Zapata Olivella's works with a critical eye on his literary production as "heretical" and radical works, within the framework of the rhetoric of national identity and postcolonial intellectual thought.

Referencing Anthony Brogues' Black Heretics, Black Prophets (2003) in his analysis of Zapata Olivella's work, Palacios acknowledges the Colombian author's intentions to "repensar la diáspora por medio de una reconfiguración de la cartografía conceptual que se refiere a los conceptos de 'raza', 'etnia”, y diáspora', tanto en la crítica cultural local colombiana como en la críticia cultural latinoamericana" and beyond (11). Divided into five very dense chapters, this study proposes to demonstrate that Manuel Zapata Olivella was an intellectual whose writing proposed to "hacer inteligble la dislocación sujeto-comunidad de la afrodiáspora Colombia y más allá de sus fronteras imaginadas" (12). Each chapter opens with a very deep study of the criticism published about Zapata Olivella's writing as articulations of the African Diaspora in Latin America and continues examining further these articulaciones relevant to the heretical and prophetic writing, the political writing of the black author in Latin America. Palacios opens his first chapter with a focus precisely on the literary criticism produced in the US on the afro diasporic literature in Spanish in his attempt to demonstrate what he calls the "necesidad de ampliar el espectro de las interpretaciones sobre la producción intellectual de [Zapata Olivella]" in order to go beyond the tendency to see him solely as a "literato" but also recongnize Manuel Zapata Olivella as a great thinker that "articula una amplia crítica de la historia y la cultura características del intellectual afrodiaspórico hereje, radical y profético (11). Citing the 1970 s as the decade that produced the first significant studies on black writing in Latin America, Palacios delves into some of the seminal works of two of the bestknown scholars of Afro Latin American literature, beginning with Richard L. Jackson and Marvin A. Lewis. He states that Jackson argued for the meticulous study of black writers' works, as it would be necessary to raise awareness of these authors and to show the aesthetic, cultural, and interpretive value of their works to ensure an opening of the literary canon, as well as an understanding of the process of racialization in Latin America. Palacios reminds us that Jackson describes Manuel Zapata Olivella's works as "the most exhaustive and one of the most important expressions in the Latin American context from Colombia" (13) For Palacios, Lewis' articles about Zapata Olivella's novels and his 1987 monograph Treading the Ebony Path: Ideology and Violence in Contemporary Afro-Colombian Prose Fiction "construct a cartography of the fiction produced by afrocolombian authors in terms of the importance of the ethnic question as a backdrop for his aesthetic production and show how said production relates to Colombian society in general terms" (14). Whether Palacios thinks the perspectives of these scholars about Zapata Olivella's work is positive remains to be seen; Palacios seems to be ambivalent on the matter. What is certain is that after locating and considering all the early literary criticism published about Zapata Olivella's works, Palacios skillfully articulates the literary criticism of Zapata Olivella's work with other studies about the African diaspora in Latin America, with special attention to Haiti to demonstrate the strength of heretical and radical political thought in the context of African diaspora. 
In the second chapter, the critical writing of anthropologists George Reid Andrews and Peter Wade take center stage as Palacios explores the twin concepts of race and mestizaje in the rhetoric of the Colombian nation-state. Palacios' examination of Zapata Olivella's prose further perpetuates the characteristic "darkening" or oscurimiento of Colombian literature. The discussion of the appropriation of elements of African culture as expressed in music, dance, and religions of Latin America by the white elite in Latin America, elements once abandoned out of shame of their non-european origins, are re-evaluated in the second and third decades of the 2oth century, when race mixture or mestizaje not only formed a part of the national identity of these countries, but also served as evidence of the racial democracy that some nations purported had made racial discrimination a non-issue in their societies. In this chapter, the texts of cultural criticism of Gilberto Freyre, Fernando Ortiz, José Vasconcelos, José Carlos Mariátegui, José Enrique Rodó and Carlos Siso are highlighted as examples of the use of the concept of national identity in the debate about race and nation formation in Brazil, Cuba, Mexico, Peru, the countries of the Southern Cone, and Venezuela, respectively. But while the discourse of racial democracy was really about achieving the ideal of whiteness as a prerequisite to citizenship, Palacios argues it ran in opposition to the actual intentions of bourgeois society that equated blackness and indigeneity to racial inferiority and barbarism. As he deconstructs the ideals of national identity in the writings of Colombian intellectuals of the Independence period-Francisco José de Caldas, José María Samper, and Luis López de Mesa, Palacios confirms that racial democracy was indeed a myth because it did nothing more than give an impression of the existence of a raceless society in nations that intended to erase afrodescendientes and indígenas from the national portrait for the sake of "modernity" and "progress" (62). Palacios' thorough dissection of Colombian rhetoric on national identity soon gives way to an explanation of the world in which Manuel Zapata Olivella was born, which, in turn, is itself the motivation of the heretical and prophetical writing that he would produce over his sixty years of literary production. While Palacios takes care to detail the history of the role the ideology of race has had in the development of Colombia, he is actually providing the reader with the context of the foundations of Zapata Olivella's first political writing of the 1930s and his unsurprising friendship and mutual admiration with the African American writer Langston Hughes.

The third chapter delves into Zapata Olivella's travel writing, written as he traversed the continents of North America and Asia in the 1940s and 1950s, during which time he produced three autobiographical travel texts: Pasión Vagabunda (1949), He visto la noche (1953), and China 6 am (1955). Palacios notes that the genre of these three texts, in particular, have proven difficult for literary critics to categorize. While for some, like François Bignolo, they exemplify travel narratives, Palacios signals that for Marvin A. Lewis, the afrocentric perspective that serves as the thematic thread that binds all of Zapata Olivella's works in fiction gives these three works makes them more autobiography than travel writing (103). Admittedly, while the importance of the categorization of these and any of Zapata Olivella's works may seem trivial, it is here where Palacios' objectives upon writing this monograph reveal themselves. When discussing Lewis' perspective of these three texts, it becomes apparent that Palacios agrees that we find Zapata Olivella's expression of his racial and cultural consciousness developing in these texts. The tri-ethnic nature of Zapata Olivella's racial identity is emphasized and the conscious-raising experiences that his travels afforded him also brought him to characterize the experience of African descendants in the Americas as the common experiences of the underdog globally, as Palacios notes is evident in the incorporation of "elementos que afirman la hermandad/identidad de los pueblos" (149) in China, 6 a.m and argues that it is also here that Zapata Olivella's social activism conflates with his writing with the intention of creating a space for the racialized pueblo among the "processes of representation and power" (151, translation mine).

In the fourth chapter, Palacios continues his description of the development of Zapata Olivella's concientación racial in the 6th decade of the 2oth century, when he says, that "the accumulation of the author's experiences now transform into ideas, reflections and literary creations" are situated between Colombian, regional Spanish American and Western global ones from the perspective of an Afro Diasporic lens (153, translation mine). Palacios cites Múñera who describes this as the era of the Colombian author's dedication to the promotion of his nation's literary excellence. This "nacionalismo literario" highlights what for Zapata Olivella is the literary duty [el quehacer literario] of Spanish America: the novel. For his discussion of the socially compromised novel, Palacios largely focuses on Chambacú, corral de negros (1967). He contradicts a Colombian scholar that has written that Zapata Olivella others the black subject in the novel and asserts, at the conclusion of the chapter, that in Chambacú, Zapata Olivella accomplishes a re-articulation of familiar paradigms associated with the intersection of post-colonialism and modernity, leaving the protagonist Máximo precisely at the crossroads between his Black community and the African Diaspora.

The fifth and last chapter of this monograph examines the literary social activism of Zapata Olivella found in his last novels and essays published at the end of the twentieth and at the beginning of the twentieth centuries. In particular, Palacios focuses on the creation of the muntu americano upon its first appearance in the novel Changó, el gran putas (1983). The bantu word muntu, which refers to human beings, alive or dead, first brought to the western world through Janheinz Jahn's variably titled book Muntu in 1961, 
is ideologically imposed in Changó when its author added the word "americano"; the philosophy that Zapata Olivella espouses by using this word establishes that the African in the New World is a new man. Palacios cites Lewis in his description of the importance of the concept of synchronic vs diachronic time with the use of the muntu americano in the novel. The muntu americano is the survivor of colonialism and the very essence of the African diaspora in the confluence of ancestral memory abundant in the New World.

Further demonstrating the heretical and activist nature of Zapata Olivella's writing, Palacios argues that before Trouillot's reverence of the Haitian Revolution, Manuel Zapata Olivella had long acknowledged the importance of Mackandal and Toussaint L'Overture as America's first Black heretics and prophets to create what Trouillot refers to "a non-event", that is the largest and most impactful revolution in American history in which the Black oppressed overcome the White oppressors to form the first Black republic outside of the continent of Africa; the event that is not spoken about is "an unthinkable history". The heresy of that event committed is that they imagined themselves capable of defeating white supremacy, which the western world could not imagine possible of inferior beings believed to lack the intellect and forethought to conspire together, let alone to defeat their captors and form a government and nation of their own.

Palacios' monograph makes a deep dive into all Zapata Olivella's best works and the criticism about them to bring to the fore his own "cartography"-borrowing from the author himself - of the development of Afro Colombian and Afro Latin American literature. Palacios' investigation is well-researched and clearly shows the process of "racialization", or "darkening", of Colombian letters that decidedly goes beyond the national rhetoric of Latin American mestizaje and settles comfortably among the literature of the African Diaspora with all its textures and complexities. While not at all heavy in jargon, this book is a challenging read. Palacios cites heavily from other scholars and his prose produces long paragraphs, sometimes of only two sentences. There is more code-switching than I would like in a single sentence-but it is a necessary evil due to the fact that much of the criticism that he cites is in English. This book is written in Spanish, and that may limit its audience outside of Latin America, but for the scholar of the African Diaspora who can read Spanish, this book has much value for all fans of great writers; specifically, this is a must-own for fans of Manuel Zapata Olivella. It would be of interest also to those working with Latin American literature in general and those interested in sociopolitical writings, literary activism, and themes of race and national identity. However, I find it would be of most value to any literary scholar that wants to learn more about writers of the African Diaspora.

Dawn F. Stinchcomb, Purdue University 